\title{
Stres Menurut Sarjana Barat dan Islam
}

\author{
Stress According to the Western and Muslim Scholars
}

\author{
NOOR IZZATI MOHD ZAWAWI*, FARIZA MD.SHAM \& A’DAWIYAH ISMAIL ${ }^{1}$
}

\begin{abstract}
Stress is a psychological symptom caused by a number of factors such as biological, medical, psychological and social. It can happen to individuals regardless of age or gender. A person in a state of stress may experience some symptoms such as anxiety, fear, shortness of breath and so on. Hence, this article aims to analyze the similarities and differences of stress from an Islamic and Western perspective. Qualitative research methods are used by performing document analysis on past stress-related studies. The results show that personality and perceptions determine a person's level of stress. Western stress experts like Hans Salye and Lazarus have concluded that extreme stress can be harmful to themselves. But simple stress can motivate one to succeed. Studies have also found that Islamic scholars such as al-Ghazali have assumed that stress is a psychological symptom usually experienced by those who have lost their relationship to Allah Almighty in addition to impure heart. This is because according to al-Ghazali, the personality of an individual depends on his relationship with Allah Almighty and his relationship with humanity. The result of the study found that the greatest difference between Western scholars and Muslims in discussing stress is that Islamic scholars have made the Quran and the Sunnah a major reference in each of their studies as well as empirical studies. On the other hand, Western scholars rely solely on empirical studies. However, in recent times the combination of psychology between Islam and the West has created a holistic and effective approach with a variety of methods of coping and preventing stress that can be applied either generally or using Islamic psychology.
\end{abstract}

Keywords: Islamic psychology, spirituality, stimuli, stress, personality

Dalam Portal MyHEALTH Kementerian Kesihatan Malaysia, stres termasuk dalam kategori masalah kesihatan mental. Stres boleh berlaku kepada sesiapa sahaja termasuk kanak-kanak, remaja, golongan dewasa dan warga emas. Bagi kanak-kanak dan remaja, tindak balas yang negatif terhadap stres akan berlaku apabila seseorang itu mengalami stres yang keterlaluan dan sudah tidak mampu untuk berhadapan dengan stres (Nurashikin 2011). Kamus Dewan pula telah mentakrifkan stres sebagai keadaan seseorang yang berada dalam keadaan resah, cemas, tegang dan sebagainya akibat daripada tekanan mental atau fizikal yang berlaku ke atasnya(Noresah, Md. Nor, Ibrahim, Azizah \& Sa'idah 2005). Manakala Al-Mawrid pula telah mentafsirkan stres sebagai ضغط dalam Bahasa Arab (Ba'labakki 1996). Oleh itu, stres merupakan keadaan seseorang

\footnotetext{
${ }^{1}$ Noor Izzati Mohd Zawawi* (corresponding author), Ph.D. candidate at Centre for Human and Community Wellbeing, Faculty of Islamic Studies, Universiti Kebangsaan Malaysia, 43600 BANGI, Selangor, Malaysia, email: noorizzatimz@gmail.com; Fariza Md. Sham, Ph.D., professor at Centre for Human and Community Wellbeing, Faculty of Islamic Studies, Universiti Kebangsaan Malaysia, 43600 BANGI, Selangor, Malaysia, email: farisham@ukm.edu.my; A'dawiyah Ismail, Ph.D., senior lecturer at Centre for Human and Community Wellbeing, Faculty of Islamic Studies, Universiti Kebangsaan Malaysia, 43600 BANGI, Selangor, Malaysia, email: ada@ukm.edu.my.
} 
yang sedang tertekan emosinya yang disebabkan oleh peristiwa, pengalaman atau bebanan tugas yang di luar kemampuan mereka (Fariza 2005).

Stres merupakan punca kepada hampir semua masalah melibatkan kesihatan mental. Stres yang sederhana boleh memberi kesan positif kerana ia menolong tubuh dan minda bekerja dengan baik. Namun, stres yang terlalu tinggi pula akan memberikan kesan negatif kepada kesihatan dan pencapaian seseorang dalam apa jua bidang yang diceburinya (Abdul Rahman, Ros Aini, Majdi@ Abdul Hadi \& Rashdan 2011). Contohnya seorang pelajar yang tidak dapat mengawal tahap stres yang dialaminya akan memberi kesan kepada pencapaian akademik. Begitu juga seorang pekerja yang stres dengan pekerjaannya akan gagal untuk menunjukkan prestasi atau hasil yang baik dalam tugasannya. Stres positif terjadi apabila seseorang itu menerima sesuatu tekanan, contohnya seseorang pelajar yang akan menghadapi peperiksaan pada keesokan harinya, maka dia akan bersiap sedia dan cuba mengharungi situasi yang ada dengan usaha yang tinggi. Sebaliknya stres yang negatif akan menyebabkan seseorang itu tidak meneruskan perjuangannya menghadapi tekanan kerana timbul gejala penentangan yang disebabkan oleh tekanan yang berterusan. Oleh itu, stres perlu dibendung jika melampaui kemampuan untuk menghadapinya (Hatta 2012).

Objektif artikel ini adalah untuk membincangkan konsep stres daripada kacamata para sarjana barat dan Islam. Justeru, artikel ini bertujuan untuk menyoroti kajian lepas berkaitan dengan konsep stres berdasarkan pandangan tokoh-tokoh stres. Analisis literatur dibuat untuk mengemukakan konsep stres menurut pandangan sarjana barat dan Islam. Kajian ini berbentuk kualitatif dengan mengambil pendekatan kajian kepustakaan.

\section{Metodologi Kajian}

Kajian ini berbentuk kualitatif dengan mengambil pendekatan kajian kepustakaan melalui analisis kandungan (content analysis) untuk mengemukakan konsep stres menurut pandangan sarjana barat dan Islam dari segi persamaan dan perbezaan, faktor dan cara menangani stres.

\section{Konsep Stres Menurut Sarjana Barat dan Islam}

Kajian mengenai stres telah banyak dipelopori oleh sarjana daripada barat. Sejarah perkembangan stres sentiasa mengalami perubahan di mana pada pada masa itu, perkataan 'stres'masih belum wujud. Sebaliknya perkataan 'emosi' digunakan oleh ahli pengkaji stres untuk menggambarkan satu keadaan yang tertekan. Ahli-ahli falsafah barat juga turut membincangkan mengenai keadaan yang tertekan yang akhirnya menyaksikan wujudnya perkataan stres dan teori mengenai stres turut berkembang. Tokoh-tokoh awal stres barat terdiri daripada Aristotle pada tahun keempat S.M, St. Thomas Aquinas pada abad ke-13 S.M dan Descartes pada abad ke17 (Sapora, Khatijah \& Othman 2013).

Antara tokoh pengkaji stres Barat yang terkenal ialah Hans Salye. Salye (1993) telah mencipta Teori dan Model Stres yang dinamakan Teori Sindrom Adaptasi Am (General Adaptation Syndrome Theory) telah menegaskan bahawa stres ialah satu perubahan yang berlaku kepada diri seseorang sama ada ke atas fizikal atau mental yang disebabkan oleh sesuatu tekanan atau paksaan. Stres boleh menyebabkan seseorang itu berusaha dengan lebih kuat hasil daripada kesakitan, ketegangan dan ketakutan yang dialaminya. Bagi Tanner (1977) pula, beliau melihat stres dari sudut pandangan yang negatif. Menurut Tanner, stres akan menyebabkan seseorang itu menjadi tidak stabil kerana memerlukan pemerhatian khusus. Seseorang yang mengalami stres yang melampau boleh mengambil tindakan yang membahayakan dirinya atau orang-orang di sekelilingnya.Oleh itu, golongan ini memerlukan bantuan dan sokongan daripada keluarga dan rakan-rakan untuk mengurangkan stres yang dialami.

Pendapat yang hampir sama turut dikongsi oleh Noi \& Smith (1990) yang telah mendefinisikan stres sebagai sejauh mana tekanan atau paksaan dilakukan ke atas sesuatu. Jika 
dilakukan ke atas sesuatu objek, kesannya akan terbahagi dua sama ada akan patah atau boleh melentur (fleksibel) sewaktu mengalami tekanan. Contoh sesuatu objek yang boleh melentur ialah pokok buluh muda, manakala contoh objek yang boleh patah ialah konkrit. Begitulah juga dengan stres yang dihadapi oleh seseorang individu. Sesetengah individu boleh menghadapi stres dan memandangnya dari sudut positif. Namun, terdapat individu lain yang tidak mampu untuk berhadapan dengan stres hingga mengakibatkan kesan negatif ke atas diri mereka. Semuanya bergantung kepada persepsi seseorang terhadap sesuatu perkara atau masalah yang dihadapinya (Sapora et al. 2013)

Bhatia (2009) dalam Dictionary of Psychology and Allied Sciences dan Vanden Bos (2015) dalam APA (American Psychological Association) Dictionary of Psychology, pula telah menyatakan bahawa stres merupakan suatu rangsangan yang keterlaluan terhadap emosi sehingga mengganggu keseimbangan pemikiran dan kelakuan seseorang yang akhirnya menghasilkan tindak balas yang positif atau negatif. Stres juga dianggap sebagai tindak balas antara seseorang individu dengan sebarang rangsangan yang dianggap merbahaya dan boleh mengancam kehidupan individu tersebut (Sapora Sipon et. al. 2013). Hal ini terjadi apabila seseorang merasa bimbang kerana peristiwa atau tanggungjawab yang melebihi kebolehan dan keupayaan berdaya tindak (Kaplan 1996).

Berdasarkan pelbagai definisi stres, para pengkaji telah sepakat menyatakan bahawa perkataan stres mempunyai banyak maksud, bergantung kepada bidang dan persepsi masingmasing. Contohnya dalam bidang fizik atau kejuruteraan, stres bermaksud sesuatu yang berat atau membebankan (Wilkie n.d.). Pada masa yang sama, dalam bidang psikologi, perkataan stres lebih merujuk kepada suatu tekanan atau kemurungan yang berlaku kepada seseorang individu. Walaupun stres mempunyai pelbagai maksud, namun fokus utama lebih tertumpu kepada tekanan yang dihadapi oleh seseorang individu sehingga menyebabkan dia menjadi murung atau berada dalam kesedihan (Breznith \& Goldbenger 1993).

Dalam konteks perkembangan ilmu pada zaman ketamadunan Islam, lahir tokoh-tokoh Muslim sebagai pemikir dan ilmuwan dalam pelbagai bidang. Dalam bidang psikologi, lahir tokoh-tokoh seperti al-Farabi yang menulis Risalah fi al-'aql, Ibn Maskawaih yang menyusun buku Tahdhib al-Akhlak, Ibnu Sina dengan karya al-Shifa', Al-Mawardi dan al-Ghazali dengan karyanya Ihya' Ulum al-Din. Selain itu terdapat juga Ibn al-Jawzi dengan bukunya al-Tib al-Ridhni dan Ibn al-Qayyim dengan al-Tib al-Nabawi. Pengkajian ahli psikologi Islam yang awal lebih menumpukan kepada ilmu falsafah yang membicarakan tentang jiwa, mental, tingkah laku manusia dan hubungannya dengan konsep tazkiyyah al-nafs bagi mendekatkan diri dengan Allah (Fariza 2016: 76).

Pada masa yang sama, hubungan sesama manusia juga amat dititikberatkan oleh para Sarjana Islam. Contohnya, Al-Farabi telah berpendapat bahawa seseorang tidak akan mampu mencapai kesempurnaannya dengan sendiri melainkan dengan bantuan orang lain. Oleh itu, dalam menyelesaikan sesuatu masalah hidup seperti stres, seseorang individu hendaklah mendapatkan bantuan daripada orang lain untuk mencari jalan penyelesaian. Bagi Ibnu Sina pula, setiap tindakan manusia bergantung kepada perasaan. Hal ini dibuktikan dengan adanya perasaan malu, takut dan sebagainya. Manakala al-Mawardi menegaskan bahawa manusia amat mudah untuk merasa dengki dan iri hati terhadap orang lain. Perasaan ini boleh diatasi dengan saling bantu membantu antara satu sama lain, saling mengasihi dan menghargai (Khaidzir et al. 2016: 40-41).

Merujuk kepada hasil kajian lepas, perbezaan yang paling ketara antara kajian oleh Sarjana Barat dan Islam ialah para Sarjana Islam telah menjadikan Al-Quran dan as Sunnah sebagai rujukan utama dalam setiap kajian mereka di samping kajian empirikal. Sebaliknya, Sarjana Barat hanya bergantung kepada kajian empirikal semata-mata. Oleh itu, dalam konteks stres, para Sarjana Barat telah menumpukan punca terjadinya stres kepada diri sendiri. Tetapi para sarjana Islam pula telah bersetuju bahawa segala permasalahan jiwa seperti stres berpunca daripada kualiti hubungan seseorang individu dengan Tuhannya dan sesama manusia. Oleh itu 
dalam Islam, stres hanya boleh diatasi dengan memperbaiki hubungan dengan Tuhan di samping menjaga hubungan baik sesama manusia.

Buktinya, Fariza (2016) dalam kajiannya telah menerangkan bahawa pengharapan yang tinggi kepada Allah telah berjaya menghilangkan segala kesedihan dan kesusahan yang dialami sebagaimana kisah Nabi Yaakob a.s dalam surah Yusuf: 86. Ini membuktikan bahawa Allah adalah tempat manusia mengadu segala kelemahan dan kesulitan yang dialami dalam kehidupan seharihari. Oleh itu sebagai hamba-Nya kita hendaklah sentiasa mentaati segala perintah Allah dan meninggalkan segala larangan-Nya. Kita juga hendaklah sentiasa mengingati-Nya kerana Allah Maha Mengetahui setiap tingkah laku manusia dan isi hati manusia. Hal ini jelas berkait rapat dengan hati nurani, perasaan dan emosi manusia yang mempengaruhi setiap tingkahlaku dan perbuatan yang dilakukan. Ternyata semuanya bergantung kepada hati (al-qalb) yang merupakan pusat segala ketenangan mahupun kecelaruan jiwa manusia. Kajian yang berkaitan dengan kejiwaan dalam Islam telah dipelopori oleh al-Ghazali yang dianggap sebagai reformis dan sufi Islam yang terkenal. Menurut beliau, kebahagiaan sebenar seseorang manusia ialah apabila tingkah laku hidupnya mendapat keredhaan Allah (Fariza et al. 2015: 10-11).

Oleh itu, dari perspektif Islam, stres difahami melalui aspek yang berbeza daripada apa yang dikemukakan oleh ilmuwan barat di atas. Walaupun para ilmuwan Islam tidak menolak kajian yang dilakukan oleh para Sarjana Barat sepenuhnya, tetapi mereka tetap mempunyai pandangan yang tersendiri mengenai stres sebagaimana yang telah dijelaskan di dalam al-Quran dan al-Sunnah. Bagi Harussani (2004) stres bermaksud tekanan dan merupakan lumrah dalam kehidupan manusia yang sentiasa berhadapan dengan pelbagai ujian dan cabaran. Hanya kesabaran dan ketaqwaan yang akan menentukan tahap penerimaan seseorang terhadap ujian yang dihadapinya sebagaimana firman Allah dalam Surah al-Baqarah:155 dan 214. Maka daripada ujian dan kesusahan inilah yang akhirnya mewujudkan stres atau tekanan kepada mereka yang lemah jiwanya. Dari perspektif psikologi Islam, jiwa yang lemah kerana stres boleh dirawat dengan kaedah-kaedah spiritual Islam.

\section{Pembahagian Stres}

Merujuk kepada perbincangan ahli psikologi, didapati bahawa stres boleh dibahagikan kepada beberapa bahagian. Salye (1993) membahagikan stres kepada dua bahagian iaitu Eustress dan Distress. Eustress ini juga dikenali sebagai stres yang positif atau menggembirakan kerana akan menjadikan seseorang itu bersemangat dalam melaksanakan sesuatu perkerjaan. Hasilnya, seseorang itu akan merasai satu pengalaman manis yang memberikan kepuasan kepada dirinya. Sebagai contoh, seorang pelajar yang merasa stres dengan tarikh peperiksaan yang semakin hampir akan melipatgandakan usahanya untuk memastikan kejayaan dalam peperiksaan tersebut. Begitu juga dengan seorang pekerja yang diberi tarikh akhir (dateline) untuk menyiapkan sesuatu tugasan akan sanggup mengorbankan masa rehatnya demi untuk menyiapkan tugasan yang telah diamanahkan oleh ketuanya. Contoh-contoh lain yang disebut sebagai eustress oleh Selye ialah menguruskan sesebuah majlis perkahwinan yang gilang gemilang dan seorang atlit yang terlibat dalam sesuatu pertandingan yang besar dan membawa harapan keluarga dan negara (Rice 1999).

Manakala Distress pula merupakan stres yang akan menyebabkan seseorang itu hilang pertimbangan dan akan mengambil tindakan yang di luar dugaan. Seseorang individu yang berhadapan dengan stres ini akan dilanda kemurungan seperti enggan bergaul dengan orang ramai. Selain itu, kesihatan juga akan merosot dan mengganggu kelancaran aktiviti seharian. Bagi Selye, distress merupakan stres yang akan memusnahkan seseorang individu kerana distress berkait rapat dengan kebimbangan, ketakutan, perasaan berdebar-debar dan semua jenis perasaan negatif yang hadir dalam diri. Distress ini jika tidak dikawal akan mengakibatkan seseorang itu mengambil tindakan yang diluar kawalan seperti mencederakan diri sendiri dan ada yang sampai ke tahap membunuh diri (Rice 1999). 
Tokoh lain dalam bidang stres iaitu Lazarus pula telah membahagikan stres kepada tiga bahagian iaitu stres yang membahayakan ,stres yang menjadi ancaman dan stres yang menjadi cabaran (Lazarus 1993). Razali (2010) dalam bukunya yang bertajuk Pengendalian Stres dan Kebimbangan: Penilaian Kognitif dan Tingkahlaku menjelaskan mengenai model stres yang telah dicipta oleh Lazarus. Model ini menerangkan bagaimana fikiran seseorang individu itu bertindak apabila menerima rangsangan yang boleh menyebabkan stres. Menurut teori Lazarus, stres hanya terbentuk apabila terdapat punca stres yang boleh mengancam diri seseorang individu sama ada dalam bentuk fizikal atau psikososial, sekadar imaginasi atau benar-benar berlaku. Manakala stres yang dianggap ancaman pula ialah keadaan yang dijangkakan bakal berhadapan dengan sesuatu perkara buruk. Oleh itu, Lazarus telah menyimpulkan bahawa kewujudan stres bergantung kepada persepsi seseorang terhadap sesuatu rangsangan atau punca stres yang menganggapnya sebagai suatu ancaman atau bahaya.

Rangsangan ini merupakan punca terjadinya stres (stressor) yang bakal menghasilkan gerak balas stres. Namun begitu, tidak semua yang dianggap stres itu boleh mendatangkan stres. Ia bergantung kepada penilaian seseorang individu terhadap punca stres. Sebagai contoh, tidak semua pekerja merasa stres dengan segala tugasan yang telah diberikan oleh ketua mereka kerana terdapat sesetengah pekerja yang merasa gembira dengan tugasan yang diberikan dan sentiasa bersedia untuk melaksanakan tugas yang diberikan dengan sebaik-baiknya. Begitu juga dengan musim peperiksaan. Semua pelajar akan merasa stres dengan peperiksaan atau ujian. Namun bergantung kepada seseorang pelajar untuk menilai stres itu sebagai sesuatu yang positif atau negatif. Bagi yang menilainya sebagai sesuatu yang positif, akan menjadikan stres itu sebagai pembakar semangat untuk berjaya dalam peperiksaan dengan belajar bersungguh-sungguh. Manakala bagi yang menilai stres dari sudut yang negatif akan menjadikan stres sebagai alasan untuk mereka bermalas-malasan dan enggan mengulangkaji pelajaran. Golongan ini juga akan mudah ditimpa penyakit seperti pening kepala, sakit perut dan perasaan berdebar-debar. Akhirnya mereka akan memasuki dewan peperiksaan tanpa persediaan yang cukup kerana terlalu melayani perasaan stres. Stres ini pula akan berterusan apabila keputusan diumumkan dan jika keputusannya mengecewakan, stres yang dialami pelajar tadi akan menjadi lebih kronik (Mohd Razali 2010). Oleh itu, persepsi memainkan peranan penting dalam menentukan sama ada seseorang itu akan mengalami stres atau tidak. Contohnya, tidak semua orang akan mengalami stres yang teruk dengan beban kerja yang banyak, malah ada yang menganggapnya sebagai satu rahmat kerana boleh mengisi masa terluang dan menajamkan lagi kemahiran yang ada.

\section{Punca-punca Stres}

Terdapat pelbagai punca atau faktor yang boleh menyebabkan berlakunya stres. Razali (2010) menyatakan bahawa personaliti memainkan peranan penting dalam proses pengawalan stres. Personaliti merupakan gabungan antara pemikiran, sikap, akhlak dan kepercayaan seseorang individu yang membentuk cara hidup seseorang dan pandangannya mengenai sesuatu perkara. Personaliti sentiasa berubah dan berkembang seiring dengan pengalaman hidup yang telah dilalui pada masa lalu.Terdapat tiga jenis personaliti yang berkaitan dengan kesihatan mental dan mempengaruhi tahap kesihatan fizikal seseorang iaitu personaliti type $A$, personaliti type $D$ dan personaliti type $B$ (Riggio 2014).

Personaliti type $A$ dan type $D$ lebih mudah terdedah kepada stres kerana ciri-cirinya yang sukar untuk bertenang, sentiasa mengejar masa untuk mencapai apa-apa yang diingininya dan mudah kecewa atau marah jika terdapat sesuatu yang menghalang pencapaiannya. Personaliti sebegini akan mudah merasa bimbang akibat daripada stres yang dialami terutamanya type $D$. Personaliti type $D$ mempunyai tahap kebimbangan yang lebih tinggi daripada personaliti type $A$. Emosi mereka sangat sensitif dan mudah untuk berfikiran negatif terhadap sesuatu perkara. Oleh itu, dari sudut kesihatan, McLeod (2014) telah mendapati bahawa personaliti type $A$ dan type $D$ lebih terdedah kepada sakit jantung berbanding dengan personaliti type $B$ yang lebih tahan 
kepada stres. Personaliti type $B$ tidak suka mendedahkan kebolehan, kelebihan dan kejayaannya kepada orang lain, tidak mengejar masa, tidak suka bersaing dan selalu berada dalam keadaan tenang serta seorang yang peramah dan lembut tingkah laku. Personaliti jenis ini lebih tenang dalam menghadapi segala dugaan dan cabaran dalam hidup mereka (Mohd Razali 2010).

Situasi di atas bertepatan dengan pendapat Parrino (1979) dan Wolman (1973) mengenai stres yang mengatakan bahawa stres berlaku apabila seseorang itu mengalami kegagalan dalam menguruskan sesuatu perkara yang melibatkan harapan tinggi daripada orang-orang tertentu. Akibatnya dia merasakan bahawa dia sedang berada dalam persekitaran yang bahaya dan menakutkan serta mengancam kehidupannya. Perkara inilah yang sering dihadapi oleh golongangolongan tertentu seperti para remaja yang kehidupan mereka sentiasa dipenuhi dengan pelbagai tugasan dan harapan oleh pihak sekolah dan ibu bapa masing-masing.

Faktor stres yang seterusnya ialah persekitaran: Persekitaran yang tidak selesa turut menyumbang kepada stres. Suasana atau keadaan yang bising, contohnya, tembakan bertalu-talu, jeritan yang kuat dan bunyi kenderaan yang berterusan. Begitu juga dengan keadaan cuaca sama ada terlalu sejuk atau terlalu panas yang dialami seseorang apabila berada di luar negara. Faktor pencahayaan di dalam sesebuah bangunan atau bilik seperti terlalu gelap atau terlalu terang boleh mengakibatkan seseorang merasa tertekan, lebih-lebih lagi sekiranya seseorang itu terpaksa berada di kawasan tersebut dalam tempoh waktu yang lama seperti di dalam sel penjara. Di samping itu, keadaan berhabuk dan kotor seperti berhampiran kawasan pembinaan bangunan, pembinaan jalan raya, kawasan pembuangan sampah dan lain-lain turut menyumbang kepada tekanan (Mohd Juraimy \& Ahmad Azan 2013).

Psikososial juga boleh menyebabkan stres terutamanya golongan remaja. Golongan ini sering berhadapan dengan masalah dalam perhubungan sama ada sesama rakan sebaya, ahli keluarga dan orang-orang di sekeliling mereka seperti guru, jiran dan sebagainya. Keadaan akan menjadi lebih parah apabila berlaku keruntuhan rumahtangga akibat daripada penceraian. Hal ini mengakibatkan hubungan antara ibu, ayah dan anak-anak menjadi renggang dan mengakibatkan tekanan di kalangan mereka. Selain itu, konflik di tempat kerja juga boleh berlaku berpunca dari hubungan tidak baik di antara majikan dengan pekerja dan di antara pekerja dengan pekerja (Mohd Juraimy \& Ahmad Azan 2013)

Fariza (2005) serta disokong oleh para ilmuwan Islam seperti Imam al-Ghazali, Muhammad Uthman Najati dan Muhammad Izzudin Taufik telah berpendapat bahawa punca terjadinya stres ialah kita jauh daripada Allah. Stres juga dikatakan wujud jika seseorang itu mempunyai hati yang kotor seperti hasad dengki, sombong, 'ujub dan riak. Ini adalah kerana mereka yang menghidap penyakit hati ini sentiasa ingin melihat kejatuhan dan kemusnahan orang lain. Mereka tidak akan merasa senang jika orang lain lebih daripada mereka. Mereka akan sentiasa berusaha mencari jalan untuk memastikan kemusnahan atau kegagalan orang lain. Mereka akan berpuas hati melihat kegagalan orang lain. Contoh perasaan hasad yang keterlaluan boleh dilihat dalam kisah Nabi Yusuf a.s yang menjadi mangsa kedengkian abang-abang baginda. Abang-abang Nabi Yusuf a.s telah merasakan bahawa ayahanda mereka iaitu Nabi Yaakob tidak berlaku adil kerana lebih menyayangi Yusuf dan adiknya Bunyamin. Kisah ini ada dinyatakan dalam Surah Yusuf ayat 7-9. Golongan yang mempunyai hati yang kotor akan mudah terpengaruh dengan hasutan syaitan yang sentiasa berusaha untuk menyesatkan umat manusia.

Setiap individu tidak akan terlepas daripada mengalami stres dalam kehidupan seharihari. Semua golongan bermula daripada bayi, kanak-kanak, remaja, dewasa dan warga emas akan mengalami stres yang berbeza, bergantung kepada situasi yang mereka hadapi. Sebagai contoh, seorang bayi dan kanak-kanak akan merasa stres jika berjauhan dengan ibunya ataupun ketika lapar. Kanak-kanak juga akan merasa stres dengan tekanan-tekanan yang dihadapi di sekolah dan masalah dengan rakan sebaya. Pada peringkat usia remaja pula, faktor-faktor seperti pelajaran, hubungan dengan rakan sebaya dan keluarga serta masalah pengurusan masa merupakan pencetus stres kepada mereka. Hal ini bersesuaian dengan pengertian zaman remaja yang merupakan zaman perubahan atau peralihan daripada kanak-kanak kepada dewasa. Pada usia 
remaja, tugas, tanggungjawab, keistimewaan dan hubungan sosial dengan orang sekeliling juga akan turut berubah (Ausubel, Montemayo \& Svajia 1977: 16). Faktor-faktor ini akan menyebabkan remaja sentiasa berada dalam keadaan tertekan dan kebimbangan. Pada masa yang sama mereka juga dibebankan dengan harapan ibu bapa dan guru untuk melihat kejayaan mereka (Rozita, Sohana \& Marhaini 2019). Semua ibu bapa amat mementingkan kejayaan dalam pendidikan untuk anak-anak mereka kerana pendidikan mempunyai impak yang besar dalam menentukan kualiti hidup seseorang individu. Dalam kebanyakan situasi, pelajar atau remaja yang datang daripada keluarga berpendidikan rendah lebih cenderung untuk gagal dan bermasalah di sekolah, jika dibandingkan dengan pelajar yang berasal daripada keluarga yang baik dan berpendidikan tinggi (Affizal 2008).

Golongan dewasa merupakan peringkat umur yang paling kerap mengalami stres disebabkan oleh pelbagai masalah dan tanggungjawab dalam kehidupan seharian. Masalah di tempat kerja merupakan antara faktor stres yang tidak boleh dipandang ringan. Situasi ini berbeza pula dengan warga emas yang turut mempunyai stres mereka sendiri. Kesunyian dikenalpasti sebagai masalah kesihatan mental utama warga tua. Warga tua berisiko mengalami kesunyian kerana kehilangan dan perubahan hidup. Kematian pasangan dan anak-anak yang tinggal berjauhan merupakan antara faktor penyumbang kepada kesunyian di kalangan warga emas. Selain itu, kurangnya sokongan sosial, ketidakupayaan fizikal, dan penyakit kronik boleh meningkatkan lagi risiko kesunyian di kalangan warga tua. Golongan ini merasakan mereka sentiasa menjadi beban kepada anak-anak. Manakala bagi warga tua yang tinggal berjauhan daripada keluarga atau ditempatkan di institusi penjagaan warga tua lebih terdedah kepada kesunyian dan kesedihan kerana merasa mereka diabaikan (Siti Marziah, Khadijah \& Nasrudin 2013).

\section{Simptom Stres}

Stres akan menyebabkan perubahan pada setiap sistem dalam badan manusia dan akan mempengaruhi perasaan dan tindakan seseorang individu. Sebagai contoh, dapat dilihat pada tanda-tanda seperti jantung yang berdegup laju, berpeluh, nafas yang tersekat-sekat dan mulut yang menjadi kering (Bhatia 2009). Stres yang lebih teruk akan mengakibatkan perubahan pada pemikiran dan tubuh badan seseorang seperti kemurungan hingga jatuh sakit dan mempengaruhi kualiti kehidupan (VandenBos 2015). Stres juga boleh menyebabkan tekanan darah tinggi, meningkatnya tahap kolesterol dalam badan, sakit perut, loya dan sebagainya (Fatimah Wati Halim \& Wan Shahrazad Wan Sulaiman 2001). Selain itu, seseorang yang mengalami stres juga akan mengalami pelbagai penyakit seperti gangguan pada saluran pencernaan, asma, sakit kepala dan penyakit kulit. Dia juga akan menjadi seorang yang mudah marah, sering berada dalam keadaan keliru dan sukar untuk menerima kenyataan jika sesuatu perkara berlaku ke atas dirinya. Terdapat juga sesetengah kes yang berakhir dengan kematian (Salye 1993).

Tanda-tanda stres menurut Sarjana Islam dapat dilihat dari sudut kegelisahan jiwa atau emosi manusia seperti perasaan gelisah, kecewa, bimbang yang keterlaluan dan takut (Fariza 2005). Selain itu, keletihan dan ketegangan juga boleh menyebabkan stres. Situasi panik, perasaan gemuruh, kebimbangan dan kemurungan juga merupakan antara gejala-gejala stres yang sering berlaku. Simptom-simptom ini akan menyebabkan hilang daya yang biasa berlaku apabila berlakunya perubahan pada tubuh badan atau fikiran sendiri. Perasaan bimbang yang keterlaluan juga boleh menyebabkan stres (Al-Munajjid 2006).

Dalam surah Al-Ma'arij ayat 19 dan surah al-Balad ayat 4 Allah telah menyatakan bahawa manusia itu sentiasa berada dalam keadaan resah gelisah dalam menjalani kehidupan di atas muka bumi ini termasuklah para nabi dan rasul. Kesusahan hidup dan keresahan hati hanya akan berakhir apabila berada di dalam syurga Allah yang penuh dengan kesenangan dan kenikmatan sebagaimana firman Allah dalam surah al-Hijr ayat 45-47 dan al-Waaqi'ah ayat 15-23 (Al- 
Munajjid 2006). Fariza (2005) juga turut berpendapat bahawa jiwa kacau dan tidak tentu arah, sentiasa merasa resah, sedih, mudah terpengaruh dengan hawa nafsu dan tidak merasa bersalah melanggar perintah Allah merupakan antara simptom-simptom stres dalam Islam.

\section{Cara-cara Menangani Stres}

Menurut Salye (1993), seseorang yang mengalami stres akan menggunakan pelbagai cara untuk menghilangkan atau mengurangkan tekanan yang sedang dialaminya. Antara usaha yang dilakukan ialah dengan melakukan aktiviti-aktiviti lasak seperti mendaki gunung, menyelam, meredah hutan dan sebagainya. Sebahagian daripada mereka dapat mengatasi stres yang dialami dengan melawan kembali stres tersebut dan ada yang dapat mengatasinya secara beransuransur. Golongan remaja pula memerlukan bantuan dan sokongan daripada orang-orang di sekeliling mereka untuk mengatasi stres (de Anda, Baroni \& Boskin 2000)

Razali (2010) telah mencadangkan beberapa cara untuk bertindak secara proaktif untuk mengelakkan stres dan tidak menunggu sehingga berlakunya stres untuk mengambil sesuatu tindakan pencegahan. Antara langkah dan amalan yang boleh dilakukan untuk menghindari stres ialah mengamalkan gaya hidup sihat, pengurusan masa yang baik dan bersifat asertif atau tegas dalam mengejar wawasan hidup. Stres juga boleh dielakkan dengan bantuan dan sokongan sosial daripada kaum keluarga dan rakan-rakan. Golongan kanak-kanak dan remaja terutamanya amat memerlukan sokongan sosial ketika mereka mengalami stres. Begitu juga dengan warga emas yang sentiasa memerlukan teman untuk menghilangkan kesunyian. Selain itu kemahiran komunikasi dan penyelesaian konflik amat diperlukan oleh seseorang pekerja untuk mengelakkan stres di tempat kerja.

Secara ringkasnya, stres merupakan penyakit emosi yang dialami oleh semua peringkat umur dalam menjalani kehidupan seharian. Setiap individu mempunyai masalah tersendiri yang menyebabkannya menjadi stres. Terdapat masalah yang boleh diselesaikan dalam masa yang singkat dan ada juga yang mengambil masa yang lama untuk menyelesaikannya. Dalam semua keadaan, seseorang yang sedang berada dalam keadaan stres memerlukan ketenangan hati dan kelapangan fikiran untuk menyelesaikan sesuatu masalah yang sedang dialami (Mohd Taib \& Hamdan 2006).

Sebagai seorang Muslim, jika ditimpa sesuatu penyakit kita hendaklah berikhtiar untuk mengubatinya. Stres merupakan salah satu masalah kesihatan mental dan kejiwaan yang merbahaya jika tidak dirawat. Selain daripada rawatan moden, rawatan tradisional yang berasaskan ayat-ayat Al-Quran juga dipercayai dapat mengurangkan dan seterusnya merawat stres. (Faisal@ Ahmad Faisal \& Nurul Wahidah 2012: 152). Ini adalah kerana menurut konsep perubatan Islam, kehebatan penggunaan ayat-ayat al-Quran untuk mengubati sesuatu penyakit tidaklah dapat ditandingi. Antara kaedah merawat stres di dalam Islam ialah mendekatkan diri dengan Al-Quran (Abdul Malik 2005: 1). Seseorang yang sedang stres hendaklah membaca, mentadabbur dan mengamalkan segala ajaran yang terdapat di dalam al-Quran. Dalam surah arRa'd ayat 28, telah dinyatakan bahawa dengan berzikir akan dapat menenangkan hati. Manakala dalam surah as-Syarh ayat 6 pula terdapat janji Allah bahawa setiap kesusahan akan disertai dengan kemudahan. Ayat-ayat ini merupakan ubat yang berkesan untuk mereka yang sedang berada dalam keadaan stres. Selain itu, pengambilan madu dan susu yang beberapa kali disebut dalam Al-Quran juga merupakan salah satu cara untuk mengurangkan stres.

Untuk masalah stres di kalangan kanak-kanak, para ibu bapa hendaklah peka dengan perubahan anak-anak mereka dan cuba memujuk agar anak bersedia untuk berkongsi masalah mereka (Rajini 2015) kerana pada kebiasaannya kanak-kanak sukar untuk meluahkan masalah atau tekanan yang mereka hadapi dan rasai kepada ibu bapa. Manakala untuk golongan remaja, selain daripada peranan ibu bapa, kajian yang dibuat oleh Halimah dan Zainab (2015) telah mencadangkan agar kaunselor Muslim di sekolah-sekolah dapat mempergiatkan lagi usaha dalam menangani salah laku pelajar secara afektif melalui program pencegahan yang bersifat 
holistik dan seimbang meliputi aspek jasmani, emosi, rohani dan intelek (JERI). Pada masa yang sama, masyarakat sekeliling haruslah memainkan peranan untuk mengubati jiwa yang rosak ini. Usaha dakwah dengan uslub yang sesuai haruslah diperbanyakkan untuk mencegah perkara ini daripada menjadi lebih parah dan menjadi barah kepada umat Islam. Seterusnya mengamalkan sifat-sifat mahmudah dalam kehidupan seharian seperti bersedekah dan melazimi amalanamalan sunat juga dipercayai dapat mengurangkan stres. Solat pula dapat mengurangkan stres dan meningkatkan kualiti hidup seseorang pekerja (Achour et al. 2019). Bagi warga emas pula, aktiviti-aktiviti kerohanian telah terbukti dapat mengurangkan stres dan memberi kesan positif kepada kesihatan mental (Mohammad et al. 2019).

Dalam Islam, semakin besar tekanan dan ujian yang dihadapi, semakin besar pahala di sisi Allah. Ganjaran pahala akan diperolehi bagi mereka yang mampu menghadapi tekanan dengan baik. Keimanan seseorang juga akan bertambah dan berkurang, bergantung kepada tekanan yang dihadapi dan cara menanganinya sebagaimana firman Allah dalam surah al-Nahl ayat 97. Stres boleh berlaku kepada semua golongan manusia, termasuk para Nabi yang sentiasa berhadapan dengan tekanan sewaktu berdakwah kepada umat mereka. Namun para nabi mempunyai kesabaran yang tinggi sewaktu berdakwah terutamanya nabi-nabi yang mendapat gelaran Ulul Azmi, iaitu nabi-nabi yang mempunyai kecekalan hati dan kekuatan iman serta banyak menerima tentangan dari kaum mereka. Nabi Nuh merupakan salah seorang rasul Ulul Azmi yang sabar berdakwah sehingga 950 tahun, tetapi hanya sedikit yang mengikut ajaran baginda. Kisah baginda telah dinyatakan beberapa kali di dalam al-Quran. Antaranya dalam surah al-A'raf ayat 59-64, Yunus ayat 71-73, Hud ayat 25-49, al-Anbiya' ayat 76-77, Mu'minun ayat 2330, al-Syu'ara' ayat 105-122, al-Ankabut ayat 14-15, Nuh ayat 1-27 dan lainnya. Namun terdapat juga Nabi yang tidak dapat menahan kesedihan mereka setelah dakwah ditolak oleh kaumnya. Antaranya kisah Nabi Yunus yang telah meninggalkan kaumnya kerana kecewa dengan kedegilan mereka diceritakan dalam surah al-Anbiya' ayat 87-88. Kisah Nabi Yunus ini jelas menunjukkan bahawa para Nabi dan Rasul juga tidak dapat lari daripada perasaan sedih dan kecewa setelah segala usaha dakwah mereka ditolak, malah dihina oleh kaum mereka. Ini adalah kerana para nabi dan rasul juga merupakan manusia biasa yang mempunyai hati dan perasaan serta tahap kesabaran yang berbeza antara satu sama lain.

\section{Perbandingan Stres Barat dan Islam}

Perbandingan stres menurut Sarjana Barat dan Islam boleh dibahagikan kepada beberapa bahagian. Perbandingan pertama ialah dari segi konsep stres. Bagi Sarjana Barat, stres atau tekanan merupakan tindak balas seseorang terhadap sesuatu rangsangan yang keterlaluan dan dianggap merbahaya serta mengancam kehidupan. Akibat daripada stres akan menghasilkan tindakan positif atau negatif. Contoh tindakan positif ialah stres dapat menjadi motivasi kepada seseorang untuk lebih berusaha. Tetapi tindakan negatif pula ialah stres boleh menyebabkan seseorang itu berniat untuk membunuh diri. Manakala konsep stres menurut Sarjana Islam pula amat mementingkan penglibatan hati (al-qalb) dalam kehidupan seseorang Muslim kerana hati merupakan sumber kerohanian yang terpancar kepada seluruh diri manusia (Sapora, Khatijah \& Othman 2013: 64) sebagaimana Sabda Rasulullah:

Ingatlah dalam jasad kamu itu ada seketul daging, jika ia baik, maka baiklah jasad seluruhnya. Jika ia rosak, maka rosaklah jasad seluruhnya. Ketahuilah bahawa daging itu adalah al-Qalb (Riwayat Bukhari dan Muslim daripada Nu'man Bin Basyir).

Menurut al-Ghazali, hati (al-qalb) mempunyai dua pengertian. Pengertian pertama dinamakan hati jasmani, iaitu segumpal daging yang terletak di sebelah kiri dada manusia. Manakala pengertian kedua ialah hati rohani yang bermaksud hakikat insan yang mampu untuk 
menuntut ilmu dan bertanggungjawab terhadap segala perintah dan larangan Allah (Fariza, Salasiah Hanin \& Mohd Jurairi 2015: 29). Oleh itu baik atau buruk hati seseorang Muslim akan mempengaruhi tahap stres yang dialaminya. Dengan kata lain, kualiti hati (al-qalb) akan menentukan tahap stres seseorang Muslim.

Perbandingan kedua pula ialah punca-punca stres menurut Sarjana Barat dan Islam. Tidak banyak perbezaan antara Sarjana Barat dan Islam dalam menentukan punca-punca stres. Punca stres yang utama ialah personaliti yang memainkan peranan penting dalam menentukan tahap stres seseorang. Para ilmuwan Islam dan sarjana Barat mempunyai pandangan tersendiri tentang personaliti. Sarjana Barat berpendapat bahawa personaliti berpunca daripada faktor luaran seperti persekitaran, didikan dan sebagainya. Manakala ilmuwan Islam seperti al-Ghazali pula mengkaji personaliti manusia dalam ruang lingkup yang lebih luas, meliputi faktor dalaman dan faktor luaran. Sarjana Islam mengambil kira hubungan manusia dengan tuhannya dan hubungan manusia sesama manusia (Fariza, Salasiah Hanin \& Mohd Jurairi 2015: 29). Oleh itu, ilmuwan Islam dan Barat bersetuju bahawa personaliti dan persepsi seseorang individu terhadap sesuatu perubahan dalam hidup memainkan peranan penting untuk menentukan sama ada seseorang itu akan mengalami stres atau sebaliknya. Selain itu, faktor persekitaran dan psikososial juga turut menjadi punca stres. Persekitaran yang tidak selesa seperti keadaan yang bising dan berserabut boleh menyebabkan stres. Dari sudut psikososial pula, golongan remaja sering mengalami masalah ini. Remaja mudah merasa stres dengan masalah perhubungan dengan orang-orang di sekeliling mereka. Walaubagaimanapun, para Sarjana Islam telah bersetuju bahawa punca stres yang utama ialah iman yang lemah dan hati yang jauh daripada Allah. Hasilnya timbul pelbagai penyakit hati seperti hasad, dengki, sombong, 'ujub dan riyak (Fariza 2005).

Perbandingan ketiga antara stres Barat dan Islam ialah dari sudut pengurusan stres. Pelbagai teknik telah diperkenalkan oleh para Sarjana Barat untuk mengatasi masalah stres. Antaranya ialah dengan melakukan aktiviti-aktiviti lasak seperti mendaki gunung, berenang dan meredah hutan. Aktiviti-aktiviti ini dipercayai dapat mengurangkan stres (de Anda et al. 2000). Selain itu terdapat juga teknik pencegahan stres, di mana seseorang itu akan mengambil tindakan berjaga-jaga agar tidak berhadapan dengan stres seperti mengamalkan gaya hidup sihat, pengurusan masa yang baik dan bersifat asertif (Mohd Razali 2010). Di dalam Islam pula, seorang Muslim yang berjaya dalam hidupnya merupakan seorang Muslim yang berjaya menguruskan tekanan-tekanan atau stres yang berlaku dalam kehidupannya sehari-hari. Terdapat pelbagai cara pengurusan stres yang boleh dipraktikkan termasuklah bertemu kaunselor untuk berbincang tentang sesuatu masalah yang dihadapi. Walaupun kaunseling berasal daripada barat, namun Sarjana Islam telah mengiktirafnya sebagai salah satu cara pengurusan stres. Formula kepada kaunseling Islam adalah bersandarkan kepada al-Quran dan as-Sunnah (Md Noor, Nurul Ain \& Norazani 2016) iaitu saling nasihat menasihati dan memberi bimbingan yang sewajarnya kepada yang memerlukan. Oleh itu peranan orang sekeliling amat penting untuk membantu mereka yang sedang berhadapan dengan stres. Walaupun dalam Islam pergantungan kepada Allah merupakan sesuatu yang amat penting, namun pada masa yang sama seseorang yang stres tetap memerlukan sokongan emosi daripada orang-orang yang rapat dengan mereka. Para ibu bapa dan guru perlu memainkan peranan penting untuk membantu anak-anak remaja berada dalam keadaan stres. Hal ini kerana anak remaja masih belum matang fikirannya dan mudah terjerumus kepada jalan penyelesaian yang negatif jika tidak mendapat bimbingan yang sewajarnya.

Perbandingan terakhir antara stres Barat dan Islam ialah kesan-kesan stres. Dari sudut kesan stres kepada individu, kedua-dua sarjana daripada barat dan Islam telah sependapat bahawa stres yang berada pada tahap sederhana boleh menjadi motivasi kepada seseorang tetapi stres yang keterlaluan akan membawa kesan buruk sehinggakan boleh menyebabkan seseorang itu ingin membunuh diri. Para tokoh stres menjelaskan bahawa sesuatu tekanan boleh memberi kesan positif atau negatif kepada seseorang individu (Harussani 2004). Antara kesan positif yang 
sering terjadi ialah dengan tekanan yang dihadapi, seseorang itu akan bekerja dengan lebih keras, membina daya kreativiti yang tinggi, membina keyakinan diri dan membentuk peribadi yang lebih mantap dan berdisiplin. Walaubagaimanapun, sisi negatif tekanan kepada seseorang individu pula ialah boleh mengganggu emosi dan fizikal yang akhirnya boleh membawa kepada gejala-gejala negatif yang lain. Contohnya bagi kanak-kanak yang sedang membesar, jika stres dibiarkan berterusan, perkembangan rohani dan mental kanak-kanak tersebut akan terganggu. Manakala kesannya akan dapat dilihat apabila kanak-kanak ini meningkat dewasa (Fontana 1996). Remaja yang stres pula akan mudah terlibat dengan kes salah laku di sekolah (Halimah \& Zainab 2015). Kesan stres kepada golongan dewasa pula lebih merbahaya. Bermula daripada masalah di tempat kerja akan membawa kepada masalah-masalah lain yang lebih serius. Selain itu, seseorang pekerja yang mengalami stres di tempat kerja akan mempengaruhi kualiti kerja mereka. Pada masa yang sama pekerja ini juga akan menjadikan ahli keluarga mereka sebagai tempat melepaskan kemarahan mereka. Hal ini akan menyebabkan isteri dan anak-anak turut merasa stres apabila terpaksa berhadapan dengan ketua keluarga yang stres (Zafir, Nor Liza \& Nor Azwan 2013). Kajian telah membuktikan bahawa individu yang berada di bawah tahap stres yang sederhana dan tinggi memperolehi pencapaian akademik yang kurang berbanding dengan pelajar yang mempunyai tahap stres yang biasa. Mekanisme yang menunjukkan punca pelajar memperolehi prestasi yang buruk disebabkan oleh stres adalah cara pemikiran mereka sendiri. Jika mereka mudah menyerah kalah dan berputus asa, semangat mereka untuk belajar akan merudum dan mereka tidak akan berusaha untuk meningkatkan pencapaian akademik yang sepatutnya (Nur Faridah Hanim 2007).

Kajian ini telah mendapati bahawa stres merupakan sesuatu yang penting kerana ia boleh menjadikan seseorang itu berjaya atau gagal dalam hidup. Situasi, persekitaran, perubahan dalaman dan luaran serta kecelaruan emosi merupakan unsur-unsur stres dan cara seseorang itu menanganinya akan menentukan sama ada dia akan mengalami stres atau sebaliknya. Jika tidak mampu menangani unsur-unsur tersebut, individu tersebut akan berhadapan pula dengan satu masalah lain, iaitu kebimbangan. Sesetengah individu akan terperangkap dalam perasaan bimbang yang berpanjangan, manakala terdapat individu lain yang menjadikan kebimbangan itu sebagai 'batu loncatan' untuk mencapai sesuatu kejayaan (Mohan 1997). Sebagai kesimpulan, kedua-dua sarjana barat dan Islam telah bersetuju bahawa kehidupan ini merupakan satu tekanan atau stres dan seseorang itu tidak perlu merasa takut dengan tekanan yang akan sentiasa hadir dalam hidupnya.

\section{Penghargaan}

Penghargaan ditujukan kepada Geran Penyelidikan AP-2017-001/3.

\section{References}

Abdul Malik Mujahid. 2005. How A Muslim Should Deal With Stress And Anxiety. IslamiCity Forum. https://www.islamicity.org/forum/forum_posts.asp?TID=24. Retrieved: 14 July 2019.

Abdul Rahman Yaacob, Ros Aini Ibrahim, Majdi@ Abdul Hadi Ishak \& Rashdan Rashid. 2011. Punca Stres Di Kalangan Pelajar Politeknik Tuanku Syed Sirajuddin. PTSS Digest, Perlis. www.ptss.edu.my/V6/index.php?option.com_docman. Retrieved: 23 February 2018.

Achour, M., Asmawati Muhamed, Abdul Halim Syihab, Mohd Roslan Mohd Nor \& Mohd Yakub Zulkifli Mohd Yusoff. 2019. Prayer Moderating Job Stress Among Muslim Nursing Staff At The University of Malaya Medical Centre (UMMC). Journal of Religion and Health: 1-19. doi:10.1007/s10943-019-00834-6.

Affizal Ahmad. 2008. Kepentingan Pendidikan Dalam Pembentukan Kualiti Hidup Sejahtera. Malaysian Education Dean's Council Journal 2: 1-3. from http://web.usm.my/education/ 
MEDC/Vol2/1. Retrieved: 9 July 2019.

Al-Munajjid, S. M. S. 2006. Dealing with Worries and Stress. www.islam-qa.com/index.php,2006. Retrieved: 2 March 2017.

Ausubel, D. P., Montemayor, R. \& Svajian, P. (Najarian). 1977. Theory and Problems of Adolescent Development. Second. New York: Grune \& Stratton.

Ba'labakki, M. 1996. Al-Mawrid (A Modern English-Arabic Dictionary). Beirut: Dar al-'Ilm li alMalayen.

Bhatia, M. S. 2009. Dictionary of Psychology and Allied Sciences. New Delhi: New Age International (P) Limited Publishers.

Breznith, S. \& Goldbenger, L. 1993. Stress Research At A Crossroads. In. Goldberger \& Breznith (ed.). Handbook of Stress: Theorotical and Clinical Aspects. 2nd ed. New York: The Free Press.

De Anda, D., Baroni, S. \& Boskin, L. 2000. Stress, Stressors and Coping among High School Students. Children and Youth Services Review 22(6): 441-463. doi:10.1016/S01907409(00)00096-7.

E Riggio, R. 2014. Are You Type A,B or D Personality? Psychology Today. www.psychologytoday.com. Retrieved: 17 July 2019.

Faisal@ Ahmad Faisal Abdul Hamid \& Nurul Wahidah Binti Fauzi. 2012. Perubatan Melayu Tradisional: Kitab Tibb Pontianak. Journal of Al-Tamaddun 7(1): 149-162. doi:10.22452/jat.vol7no1.10.

Fariza Md. Sham. 2016. Elemen Psikologi Islam Dalam Silibus Psikologi Moden: Satu Alternatif. Global Journal al- Thaqafah 6(1): 75.

Fariza Md Sham. 2005. Tekanan Emosi Remaja. Jurnal Islamiyyat 27(1): 3-24. https://www.academia.edu/613357/Tekanan_emosi_remaja_Islam. Retrieved: 28 September 2016.

Fariza Md Sham, Salasiah Hanin Hamjah \& Mohd Jurairi Sharifudin. 2015. Personaliti Dari Perspektif Al-Ghazali. Bangi: UKM.

Fatimah Wati Halim \& Wan Shahrazad Wan Sulaiman. 2001. Personaliti Serta Hubungannya Dengan Sumber Tekanan, Simptom-simptom tekanan, Strategi Menangani Tekanan dan Prestasi Akademik Pelajar. Jurnal Psikologi Dan Pembangunan Manusia 17: 117-134. https://www.academia.edu/19384493/Personaliti_serta_hubungannya_dengan_sumbe r_tekanan_simtom-simtom_tekanan_strategi_menangani_tekanan_dan_prestasi_ akademik_pelajar. Retrieved: 1 October 2016.

Fontana, D. 1996. Foreword. In. Varma (ed.). Coping With Children in Stress, pp. ix-x. Hants, England: Arena Ashgate Publishing Limited.

Halimah Abdul Halim \& Zainab Ismail. 2015. Pendekatan Pencegahan Kaunselor Muslim dalam Menangani Salah Laku Pelajar Sekolah Menengah di Daerah Klang, Selangor. International Journal of Islamic Thought 8 (Dec 2015): 17-26. doi:10.24035/ijit.08.2015.003. Retrieved: 31 July 2019.

Harussani Bin Haji Zakaria. 2004. Pengurusan Stres: Satu Tinjauan Menurut Perspektif Islam. Bengkel Pengurusan Stres Menurut Perspektif Islam, pp. 2-9. Kuala Lumpur: Institut Kefahaman Islam Malaysia (IKIM).

Hatta Sidi. 2012. Keresahan: Penyakit \& Rawatan. Bangi: Penerbit UKM.

Heidari, M., Borujeni, M. G., Abyaneh, S. K. \& Rezaei, P. 2019. The Effect of Spiritual Care on Perceived Stress and Mental Health Among the Elderlies Living in Nursing Home. Journal of Religion and Health 58(4): 1328. doi:https://doi.org/10.1007/s10943-019-00782-1. Retrieved: 9 July 2019.

Kaplan, H. B. 1996. Psychosocial Stress. California: Academic Press.

Khaidzir Ismail, Jawiah Dakir, Fariza Md. Sham \& Hanina Halimatusaadiah Hamsan. 2016. Psikologi Islam: Falsafah, Teori dan Aplikasi. Selangor: Penerbit UKM.

Lazarus, R. S. 1993. Why We Should Think of Stress as a Subset of Emotion. In. Goldberger \& 
Breznith (eds.). Handbook of Stress: Theorotical And Clinical Aspects. 23th ed. New York: The Free Press, A Division of Macmillan.

McLeod, S. 2014. Type A Personality. Simply Psychology. www.simplypsychology.org/personalitya.html. Retrieved: 22 November 2017.

Md Noor Saper, Nurul Ain Mohd Daud \& Norazani Ahmad. 2016. Kesahan dan Kebolehpercayaan Modul I-Sc (Islamic Spiritual Counseling). International Journal of Islamic Thought 9 (June): 32-43. doi:10.24035/ijit.9.2016.004. Retrieved: 16 July 2019.

Mohan, V. 1997. Stress Management For You. Petaling Jaya: Pelanduk Publications (M) Sdn. Bhd.

Mohd Juraimy Haji Kadir \& Ahmad Azan Ridzuan. 2013. Strategi Menguruskan Tekanan Dari Perspektif Islam. Jurnal Hadhari 6(1): 27-41. http://www.ukm.my/jhadhari/makalah/V6n12014/hadhari v.1 final_3.pdf. Retrieved: 17 July 2019.

Mohd Razali Salleh. 2010. Pengendalian Stres dan Kebimbangan. Pulau Pinang: Penerbit Universiti Sains Malaysia.

Mohd Taib Dora \& Hamdan Abd Kadir. 2006. Mengurus Stres: Atasi Stres daripada Memudaratkan. Batu Caves: PTS Professional Publishing Sdn Bhd.

Noi, T. S. \& Smith, P. J. 1990. Managing Stress: A Guide to Asian Living. Singapore: Federal Publications.

Noresah Baharom, Md. Nor Hj. Abdul Ghani, Ibrahim Hj Ahmad, Azizah Supardi \& Sa'idah Kamin. 2005. Kamus Dewan. Kuala Lumpur: Dewan Bahasa dan Pustaka.

Nur Faridah Hanim Mokhtar. 2007. Kesan Stres Terhadap Pencapaian Akademik dan Personaliti Pelajar Politeknik. Johor: UTHM.

Nurashikin Ibrahim. 2011. Stres \& Tingkah Laku Berisiko. Kementerian Kesihatan Malaysia (Portal Rasmi MyHEALTH). www.myhealth.gov.my. Retrieved: 17 November 2017.

Parrino, J. J. 1979. From Panic to Power the Positive Use of Stress. Canada: John Wiley \& Sons, Inc. Rice, P. L. 1999. Stress and Health. 3rd ed . USA: Brooks/Cole Publishing Company.

Rozita Manap, Sohana Abdul Hamid \& Marhaini Abdul Ghani. 2019. Depression, Anxiety and Stress Among Undergraduate Students. e-Bangi Journal of Social Sciences and Humanities) 16(2): 1-7. http://ejournal.ukm.my/ebangi. Retrieved: 10 July 2019.

Salye, H. 1993. History of Stress Concept. In. Goldberger \& Breznitz (ed.). Handbook of Stress: Theoretical And Clinical Aspects. New York: The Free Press, A Division of Macmillan.

Sapora Sipon, Khatijah Othman \& Othman Abdul Rahman. 2013. Stres: Punca, Teori dan Pengurusan Efektif. Negeri Sembilan: Penerbit Universiti Sains Islam Malaysia.

Sarvananthan, R. 2015. Bantu Anak Anda Mengendali Stres. Sekretariat Pengasuhan Positif. Petaling Jaya. https://mypositiveparenting.org/ms/2015/12/27/bantu-anak-andamengendali-stres/. Retrieved: 1 July 2019.

Siti Marziah Zakaria, Khadijah Alavi \& Nasrudin Subhi. 2013. Risiko Kesunyian Dalam Kalangan Warga Tua Di Rumah Seri Kenangan. Journal of Psychology \& Human Development 1(1): 49-56. http://spaj.ukm.my/ppppm/jppm/article/view/52. Retrieved: 12 July 2019.

Tanner, 0. 1977. Stress. Nederland: Time Life International.

VandenBos, G. R. 2015. Dictionary of Psychology. Washington: American Psychological Association.

Wilkie, W. n.d. Understanding Stress Breakdown. Petaling Jaya, Selangor: Pelanduk Publications (M) Sdn. Bhd.

Wolman, B. B. 1973. Dictionary of Behavioural Science. New York: Van Nostrand Reinhold Company.

Zafir Mohd Makhbul, Nor Liza Abdullah \& Nor Azwan Hashim. 2013. Stres Di Tempat Kerja: Isu Global Dalam Melestarikan Organisasi. e-Bangi (Journal of Social Sciences and Humanities) 8(1): 041-059. http://ejournal.ukm.my/ebangi/article/view/11195/3622. Retrieved: 6 July 2019. 